About authors:

Kirgizov Igor Vitalevich, MD, PhD, Professor, Head Department of Pediatric Surgery; tel.: +79057720953; e-mail: drkirgizov@yandex.ru Minaev Sergey Viktorovich, MD, PhD, Professor, Head of Department of Pediatric Surgery with the course of additional vocational training; tel.: +79624507653; e-mail: sminaev@yandex.ru

Kachanov Aleksandr Vasilevich, MD, Assistant of Professor Department of Pediatric Surgery with the course of additional vocational training; tel.: +79283174974; e-mail: 89283174974@mail.ru

(C) Shapkina A. N., 2017

UDC 617.55-001.31

DOI - https://doi.org/10.14300/mnnc.2017.12072

ISSN - 2073-8137

\title{
ORGAN-PRESERVING TRENDS IN THE TREATMENT OF BLUNT SPLENIC TRAUMA IN CHILDREN
}

Shapkina A. N.

Institute of Surgery, Pacific State Medical University, Vladivostok, Russian Federation

\section{ОРГАНОСОХРАНЯЮЩИЕ ТЕНАЕНЦИИ В АЕЧЕНИИ АЕТЕЙ С ЗАКРЫТОЙ ТРАВМОЙ СЕАЕЗЕНКИ}

\section{А. Н. Шапкина}

\section{Институт хирургии, Тихоокеанский госуАарственный меАицинский университет, ВлаАивосток, Российская ФеАерация}

The results of conservative and operative treatment of 128 children with the blunt splenic trauma (BST) during last 21 years are presented. All patients have been examined and treated during the period from 1996 to 2016 in the Regional Children's Hospital, Vladivostok, Russia. This period was divided into stages depending on the beginning of use of various diagnostic methods and getting more experience in their use. In the absence of CT authors have developed the algorithm of tactics in BST, including ultrasonography (US) and laparoscopy (LS). The ratio of splenectomies was more than $20 \%$ initially and decreased to less level than $5 \%$ of all cases.

Keywords: blunt splenic trauma, children, conservative treatment

Представлен результат консервативного и оперативного лечения 128 детей с закрытой травмой селезенки (ЗТС) в течение последнего 21 года. Всем пациентам проведено обследование и лечение за период с 1996 по 2016 год в Краевой детской больнице №1 г. Владивостока, Россия. Этот период был разделен на этапы в зависимости от начала использования различных методов диагностики и приобретения опыта в их использовании. Был разработан алгоритм тактики при ЗТС в отсутствие возможности проведения компьютерной томографии (КТ), наличии только ультразвукового исследования (УЗИ) и лапароскопии (ЛС). Уровень спленэктомий достигал более 20 \% пациентов до разработки алгоритма и снизился до уровня менее 5 \% всех случаев ЗТС.

Ключевые слова: травма селезенки, дети, консервативное лечение

\footnotetext{
T
} he blunt abdominal traumas in children compose only $2-5 \%$ of all traumas, and among them the blunt splenic trauma (BST) is about $66.6-90 \%$. Splenectomy causes a number of the severe immune complications. The problem of the immune function of spleen was discovered by King and Schumacher [8] in 1952, who informed about 5 cases of death of children as a result of sepsis after splenectomy. Splenectomy is accompanied by number of postoperative complications, the most serious is postsplenectomy sepsis, and mortality in this case may be 50-90\%. The risk of development of the infection depends on age of the patient - the greatest risk is found in children till 2 years of age, the danger decreases by age, but never disappears completely $[6,16]$.

For the last 30 years there were no significant changes in at traumas of Gl or kidneys in children. But the treatment tactics at the BST has undergone cardinal changes; there was a tendency to avoid operations and use conservative methods. Ruptures in the case of BST seldom involve segment vessels, and at laparotomy the spontaneous arrest of bleeding is often observed. Conservative treatment includes a strict bed regimen, monitoring, nasogastric tube, the urine control, supporting of stable hemodynamics. The child stays 5-7 days in bed in ICU or surgical unit. In the presence of not-stable hemodynamics or symptoms of Gl injury, operative treatment is necessary. The percent of conservatively cured children also considerably increases if aid is provided by children's surgeons in specialized hospitals [2, 3, 9, 10].

For the decision of choice of method of treatment the most important is hemodynamics but the additional diagnostic methods are of great value too. Ultrasonography is noninvasive and informative method at BST and also at liver 
or kidney traumas $[12,14,18]$. Laparoscopy determines the character and degree of intraabdominal damage, quantity and character of a free fluid, localization of injuries, and it is not only diagnostic, but also treatment procedure [5, 19].

The aim of our research was to evaluate the changes in BST treatment in single institution during the past two decades.

Material and Methods. In this article the results of the retrospective analysis of conservative and surgical treatment of injured children under 15 years old with BST are presented. All patients have been examined and treated during the period from 1996 to 2016 in the Regional Children's Hospital, Vladivostok, Russia. Totally for the 21-year period we observed 128 children with BST.

The isolated BST was found in $63(49.2 \%)$ children, polytrauma- in $65(50.8 \%)$. BST were more common in boys - $85(66.4 \%)$, in girls - $43(33.6 \%)$. Mean age was 10.6 years (1-14 years). Falls were the most frequent cause - 49 children (38.3\%). We observed seasonal prevalence - more often children were traumatized in a warm season: from April to September - 93 children (72.7 \%) (Fig. 1).

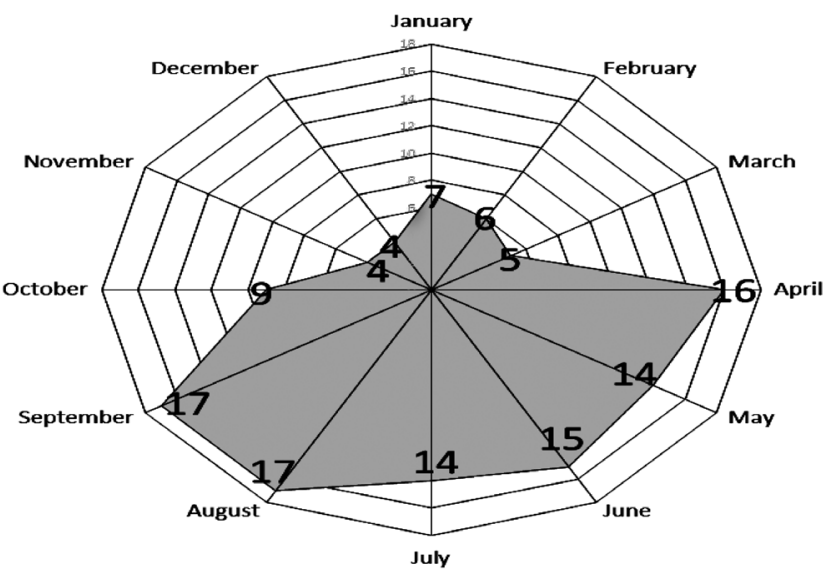

Fig. 1. Seasonal prevalence of BST in children

Results and Discussion. All patients were divided into three periods of seven years. In the first 7 years (1996-2002) there were 65 children, including 36 (55.4\%) patients with isolated and 29 (44.6\%) - with poIytrauma. During this period in our department we have started to use ultrasonography (US), and it was used in $42(64.6 \%)$ cases, we observed false-negative results in $2(4.76 \%)$ cases of 42 , DPL was used in $2(4.76 \%)$ cases. And we started laparoscopy as a diagnostic procedure. Conservative treatment was started in 38 (58.45\%) children, it became possible after the introduction of US into practice and was successful in 37 (98.37\%). 28 (43.08\%) children were operated on, beginning with laparoscopy in 16 ( 1 conversion) and in 13 cases have underwent laparotomy with splenectomy, there were no organ-preserving surgeries (Fig. 2). There were no lethal outcomes.

The second seven-year period (2003-2009) is a period of more wide use of laparoscopy resulting in less aggressive treatment. For this period 36 children, including $15(41.7 \%)$ - with isolated and $21(58.3 \%)$ - with polytrauma were treated. During this period US specialists became more skilled, and US was used in all 36 (100\%) cases, there were no false-negative results, DPL was not used. A laparoscopy was made to 5 (13.9\%) children, and in 1 case it was converted into laparotomy. Conservative treatment was provided to $27(75.0 \%)$ children, laparoscopic treatment was successful in $4(11.1 \%)$ children. Five $(13.9 \%)$ patients were operated on, two underwent splenectomy, three - splenorrhaphy (1) and partial splenectomy (2). There was 1 death in a hematologic patient due to the massive blood loss.

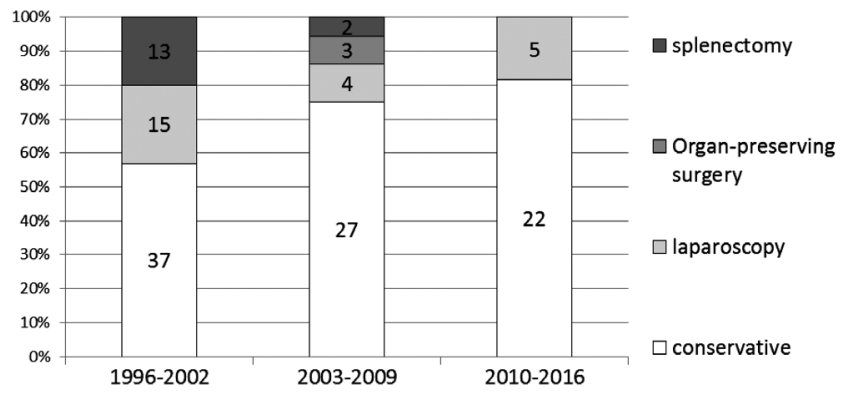

Fig. 2. Type of treatment children with BST

Last seven years (2010-2016) we have developed algorithm for BST patients, including US and laparoscopy, have determined indications and contra-indications to various methods of treatment (Fig. 3). At this period there were no splenectomy in case of splenic trauma. For this period 27 children, including $12(44.4 \%)$ - with isolated and $15(55.6 \%)$ - with a polytrauma were treated. During this period US was used in all $(100 \%)$ cases without false-negative results, DPL was not used, laparoscopy was used in $5(18.5 \%)$ children. Conservative treatment was successful in 22 (81.5 \%) children; laparoscopic treatment was successful in $5(18.5 \%)$ children. There were no open surgeries and no lethal outcomes.

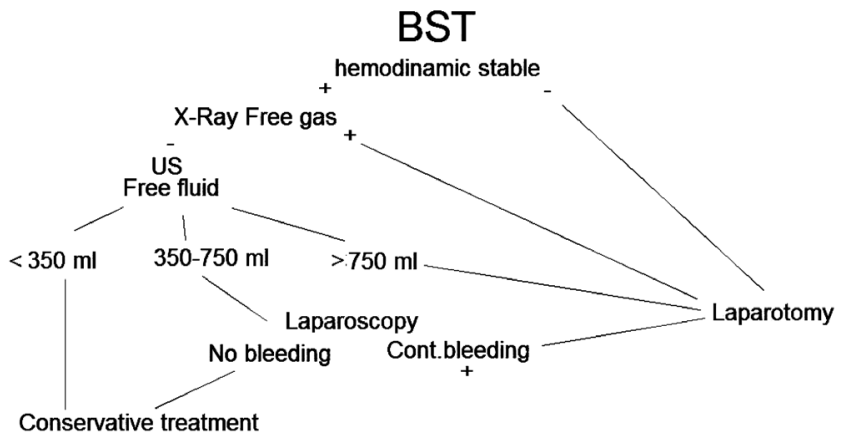

Fig. 3. Treatment algorithm of BST in children

All data are presented in the table. The decrease in number of children for last years is probably connected with less traumatism at present comparing to the period of 90 -s and the increase in polytrauma is due to diagnostic possibilities.

Results of treatment of children with the BST lead to thought on necessity of change of tactics for surgeons for this problem. The important role of spleen and possibility of organ-preserving treatment in children become those starting moments which force to emphasize the preservation of spleen or splenic tissue. According to the literature, the problem of anti-pneumococcal vaccination after splenectomy is insufficiently studied in Russia but abroad such practice is universal $[13,17]$. In our department we recommend anti-pneumococcal vaccination (vaccine Pneumo-23) to children who underwent splenectomy or splenic partial resection in case of various diseases, and also traumas.

Thus, careful monitoring of hemodynamics and application of modern diagnostic methods have given the chance of considerable restriction of surgical activity in relation to children with BST in favor of conservative therapy which became a method of choice in our hospital. Indications to conservative treatment at children with the closed trauma of a spleen is stable hemodynamics in the 
patient at presence to $350 \mathrm{ml}$ of a free fluid in children younger 7 years old in abdominal cavity by US, absence of accompanying damages of $\mathrm{Gl}$ which correlates to other publications [1, 4], 15. In the follow-up observations we did not observe any cases of adhesive complications after the conservative treatment.

In a case when to avoid the laparoscopy and/or laparotomy is impossible, it is necessary to provide organ-preserving treatment. The presence of more than $350 \mathrm{ml}$ of blood in abdominal cavity at stable hemodynamicsis is the indication to laparoscopy. At absence of a proceeding bleeding usually it is not necessary to do any manipulation except draining of abdominal cavity. Laparoscopy is often limited to survey and removal of clots and free blood from abdominal cavity.

As for laparotomy the possibility of preservation of sites of a spleen on all existing vessels can reduce considerably the possibility of immune complications occurrence. Signs of non-stable hemodynamics are: loss of consciousness, tachycardia more than 100 per minute, systolic arterial pressure on $10-15 \mathrm{~mm} \mathrm{Hg}$ lower the age norm, rate of breath more than 25 in minute or deterioration of these indicators in dynamics at the continuing infusion. In case of splenectomy it is necessary to do the auto-transplantation of splenic tissue and we recommend the subsequent vaccination. We do not support total use

\section{References}

1. Acker S. N., Petrun B., PartrickD. A., Roosevelt G. E., Bensard D. D. Lack of utility of repeat monitoring of hemoglobin and hematocrit following blunt solid organ injury in children. J. Trauma Acute Care Surg. 2015;79(6):991994. doi: 10.1097/TA.0000000000000791

2. Adelgais K. M., Kuppermann N., Kooistra J., Garcia M., Monroe D. J. [et al.] Intra-Abdominal Injury Study Group of the Pediatric Emergency Care Applied Research Network (PECARN). Accuracy of the abdominal examination for identifying children with blunt intraabdominal injuries. J. Pediatr. 2014; 165(6):1230-1235. doi: 10.1016/j.jpeds.2014.08.014

3. Bairdain S., Litman H. J., Troy M., McMahon M., Almodo$\operatorname{var} \mathrm{H}$. [et al.] Twenty-years of splenic preservation at a level 1 pediatric trauma center. J. Pediatr. Surg. 2015; 50(5):864-868. doi: 10.1016/j.jpedsurg.2014.08.022

4. De Jong W. J., Nellensteijn D. R., Ten Duis H. J., Albers M. J., Moumni M. E. [et al.] Blunt splenic trauma in children: are we too careful? Eur. J. Pediatr. Surg. 2011; 21(4):234-237. doi: 10.1055/s-0031-1273692

5. Feliz A., Shultz B., McKenna C. Diagnostic and therapeutic laparoscopy in pediatric abdominal trauma. J. Pediatr. Surg. 2006;41(1):72-77. doi: 10.1016/j. jpedsurg.2005.10.008

6. Forstner C., Plefka S., Tobudic S., Winkler H. M. Burgmann K. [et al.] Effectiveness and immunogenicity of pneumococcal vaccination in splenectomized and functionally asplenic patients. Vaccine. 2012;30(10):54495452. doi:10.1016/j.vaccine.2012.06.048

7. Hershkovitz Y., Zoarets I., Stepansky A., Kozer E. Shapira Z. [et al.] Computed tomography is not justified in every pediatric blunt trauma patient with a suspicious mechanism of injury. Am. J. Emerg. Med. 2014; 32(7):697-699. doi: 10.1016/j.ajem.2014.04.024

8. King H., Shumacher H. B. Susceptibility to infection after splenectomy performed in infancy. Ann. Surgery. 1952:6:239-244.

9. Kirkegård J., Avlund T. H., Amanavicius N., Mortensen F. V., Kissmeyer-Nielsen P. Non-operative management of blunt splenic injuries in a paediatric population: a 12-year experience. Dan. Med. J. 2015;62(2).

10. Kohler J. E., Chokshi N. K. Management of Abdominal Solid Organ Injury After Blunt Trauma. Pediatr. Ann. 2016;45(7):e241-246. doi: 10.3928/0090448120160518-01 of conservative treatment, but the individual approach to each patient is important. Our tactics is resulted in the algorithm used in our hospital now. This algorithm allows treating patients in less aggressive way and reducing operative costs in conservatively treated and reducing postoperative pain in those who require LS. The fail of conservative treatment was found in 1 patient in the first period and total number of conservatively treated patients was 86 , so the fail rate was $1.15 \%$ which is the corresponds to level of centers using CT routinely $[7,11]$.

Character of trauma in three periods

Table

\begin{tabular}{|l|c|c|c|c|}
\hline $\begin{array}{l}\text { Character } \\
\text { of trauma }\end{array}$ & $\begin{array}{c}1996-2002 \\
(n=65)\end{array}$ & $\begin{array}{c}2003-2009 \\
(n=36)\end{array}$ & $\begin{array}{c}2010-2016 \\
(n=27)\end{array}$ & $\begin{array}{c}\text { Total } \\
(n=128)\end{array}$ \\
\hline $\begin{array}{l}\text { Isolated } \\
\text { trauma }\end{array}$ & $\begin{array}{c}36 \\
(55.4 \%)\end{array}$ & $\begin{array}{c}15 \\
(41.7 \%)\end{array}$ & $\begin{array}{c}12 \\
(44.4 \%)\end{array}$ & $\begin{array}{c}63 \\
(49.2 \%)\end{array}$ \\
\hline $\begin{array}{l}\text { Polyt- } \\
\text { rauma }\end{array}$ & $\begin{array}{c}29 \\
(44.6 \%)\end{array}$ & $\begin{array}{c}21 \\
(58.3 \%)\end{array}$ & $\begin{array}{c}15 \\
(55.6 \%)\end{array}$ & $\begin{array}{c}65 \\
(40.8)\end{array}$ \\
\hline
\end{tabular}

Conclusions. Our experience shows that conservative and organ-preserving treatment for BST in children is possible even without CT with the stuff, experienced in US and LS. The cornerstone of the success is the possibility of monitoring and special intensive care department the presence of pediatric ICU with good monitoring.

11. Miele V., Piccolo C. L., Trinci M., Galluzzo M., Ianniello S. [et al.] Diagnostic imaging of blunt abdominal trauma in pediatric patients. Radiol. Med. 2016;121(5):409-430. doi: 10.1007/s11547-016-0637-2

12. Nellensteijn D. R., Greuter M. J., El Moumni M., Hulscher J. B. The Use of CT Scan in Hemodynamically Stable Children with Blunt Abdominal Trauma: Look before You Leap. Eur. J. Pediatr. Surg. 2016;26(4):332-335. doi: $10.1055 / \mathrm{s}-0035-1554804$

13. Nived P., Jørgensen C. S., Settergren B. Vaccination status and immune response to 13-valent pneumococcal conjugate vaccine inasplenic individuals. Vaccine. 2015;33(14):1688-1694. doi: 10.1016/j. vaccine.2015.02.026

14. Notrica D. M., Linnaus M. E. Nonoperative Management of Blunt Solid Organ Injury in Pediatric Surgery. Surg. Clin. North. Am. 2017:97(1):1-20. doi: 10.1016/j. suc. 2016.08.001

15. Ong A. W., Eilertson K. E., Reilly E. F., Geng T. A., Madbak F. [et al.] Nonoperative management of splenic injuries: significance of age. J. Surg. Res. 2016; 201(1):134-140. doi: 10.1016/j.jss.2015.10.014

16. Rosado M. M., Gesualdo F., Marcellini V., Di Sabatino A., Corazza G. R. [et al.] Preserved antibody levels and loss of memory $B$ cells against pneumococcus and tetanus after splenectomy: tailoring better vaccination strategies. Eur. J. Immunol. 2013; 43(10):2659-2670. doi: 10.1002/eji.201343577

17. Rubin L. G., Levin M. J., Ljungman P., Davies E. G., Avery R. [et al.] Infectious Diseases Society of America.2013 IDSA clinical practice guideline for vaccination of the immunocompromised host. Clin. Infect. Dis. 2014; 58(3): 309-318. doi: 10.1093/cid/cit816

18. Singer G., Rieder S., Eberl R., Wegmann H., Hoellwarth M. E. Comparison of two treatment eras and sonographic long-term outcome of blunt splenic injuriesin children. Eur. J. Pediatr. 2013;172(9):1187-1190. doi: 10.1007/ s00431-013-2022-7

19. Trejo-Ávila M. E., Valenzuela-Salazar C, BetancourtFerreyra J., Fernández-Enríquez E., RomeroLoera S. [et al.] Laparoscopic Versus Open Surgery for Abdominal Trauma: A Case-Matched Study J. Laparoendosc. Adv. Surg. Tech. A. 2017;27(4):383387. doi: 10.1089/lap.2016.0535

\section{About author}

